\title{
The historically high cost of tertiary education in South Africa
}

\author{
ESTIAN CALITZ AND JOHAN FOURIE
}

\section{Stellenbosch Economic Working Papers: 02/16}

KEYWORDS: SOUTH AFRICA, TERTIARY EDUCATION, UNIVERSITY, PROTESTS, BUDGET, PUBLIC ECONOMICS, FISCAL SPENDING

JEL: H52

ESTIAN CALITZ DEPARTMENT OF ECONOMICS UNIVERSITY OF STELLENBOSCH

PRIVATE BAG X1, 7602

MATIELAND, SOUTH AFRICA

E-MAIL: CALITZ@SUN.AC.ZA
JOHAN FOURIE DEPARTMENT OF ECONOMICS UNIVERSITY OF STELLENBOSCH

PRIVATE BAG X1, 7602

MATIELAND, SOUTH AFRICA

E-MAIL: JOHANF@SUN.AC.ZA

A WORKING PAPER OF THE DEPARTMENT OF ECONOMICS AND THE BUREAU FOR ECONOMIC RESEARCH AT THE UNIVERSITY OF STELLENBOSCH 


\section{The historically high cost of tertiary education in South}

Africa

ESTIAN CALITZ AND JOHAN FOURIE

\section{ABSTRACT}

The \#FeesMustFall-campaign's main objection was against the high and rising tuition fees of higher education in South Africa. This short note investigates this assertion from a historical perspective: Are university fees more expensive than a decade or a century ago? We document historical tuition fees at one of South Africa's premier universities - Stellenbosch University. The answer is an unequivocal yes.

Keywords: South Africa, tertiary education, university, protests, budget, public JEL codes: H52 economics, fiscal spending 
On Friday 23 October, South African president Jacob Zuma announced that university tuition fees will not increase in 2016. The decision was reached after a meeting that day between the president, Higher Education minister Blade Nzimande, and university vice-chancellors and student leaders following more than a week of student protests at several campuses across South Africa. Their main concern: the proposed fee increases at South African universities for 2016. A university degree, the students claimed, had become unattainably expensive.

This short note investigates whether the students were justified in their claim of high university tuition fees by considering the evolution of tuition fees over more than a century at one South African institution of higher education - Stellenbosch University. ${ }^{3}$ We find that university fees today are significantly more expensive in real terms than over the last half-century. Such an increase has not been cushioned by concomitant increases in household earnings.

\section{THE RISING COST OF HIGHER EDUCATION}

Discontent with high tuition fees in higher education is not a uniquely South African problem. In only the last three years, students have publicly protested against fee increases in Australia, Brazil, Germany, the Netherlands and the United Kingdom. ${ }^{4}$ Academics across the globe, too, have lamented the lack of government support and the associated rise in student fees; over the same period, the high tuition fees of countries as diverse as Finland, Thailand, Poland, New Zealand and Turkey have been under the headlight. ${ }^{5}$ The rising cost of higher education is clearly a global phenomenon.

\footnotetext{
${ }^{3}$ Following the lead of \#WitsFeesMustFall the previous week, a group of concerned students, organised under \#StelliesFeesMustFall, occupied an administration building on the Monday and attempted to shut down campus throughout the week to protest against a proposed fee hike of $11.5 \%$. Hours before Zuma announced the zero fee increase on the Friday, Stellenbosch University rector and vice-chancellor Wim de Villiers did the same at a mass meeting at the intersection of Merriman and Ryneveld streets.

${ }^{4}$ For Australia, see: http://www.universityworldnews.com/article.php?story=20140520104403200; for Brazil, see: https://www.jacobinmag.com/2015/07/youth-protests-dilma-rousseff-pt/; for Germany, see: https://www.timeshighereducation.com/comment/opinion/abolishing-tuition-fees-lessons-fromgermany/2017085.article; for the Netherlands, see: http://www.theguardian.com/higher-educationnetwork/2015/mar/17/dutch-student-protests-ignite-movement-against-management-of-universities; for the United Kingdom, see: http://www.theguardian.com/education/2014/nov/19/student-protest-tuition-fees-scufflespolice.

${ }^{5}$ Cai, Yuzhuo, and Jussi Kivistö. “Tuition Fees for International Students in Finland Where to Go From Here?” Journal of Studies in International Education 17.1 (2013): 55-78; Caner, Asena, and Cagla Okten. "Higher education in Turkey: Subsidizing the rich or the poor?” Economics of Education Review 35 (2013): 75-92; Chapman, Bruce, and Mathias Sinning. "Student loan reforms for German higher education: financing tuition fees.” Education Economics 22.6 (2014): 569-588; Greenaway, David, and Michelle Haynes. "Funding Higher Education in the UK: The Role of Fees and Loans." The Economic Journal 113.485 (2003): F150-F166; Kwiek, Marek. "From system expansion to system contraction: Access to higher education in Poland." Comparative Education Review 57.3 (2013): 553-576; Marshall, Stephen. "Technological innovation of higher education in New Zealand: a wicked problem?” Studies in Higher Education (2014): 1-14; Ziderman, Adrian. “Student loans in Thailand: From social targeting to cost sharing.” International Higher Education 42 (2015).
} 
South Africa was not exempt from these global trends. Figure 1 compares the annual price increases of tertiary education and boarding for the last seven years with the headline inflation rate: tertiary education and boarding prices rose significantly faster than other prices in the economy across all seven years, in some cases more than double the rate of inflation. These trends should not be surprising; in fact, several scholars have warned about the rising cost of tuition in South Africa. ${ }^{6}$ But the student protests at the end of 2015 gave new impetus to understanding the causes of these price increases, and in finding solutions to the problem.

Figure 1: Consumer price increase for university tuition, boarding fees and total

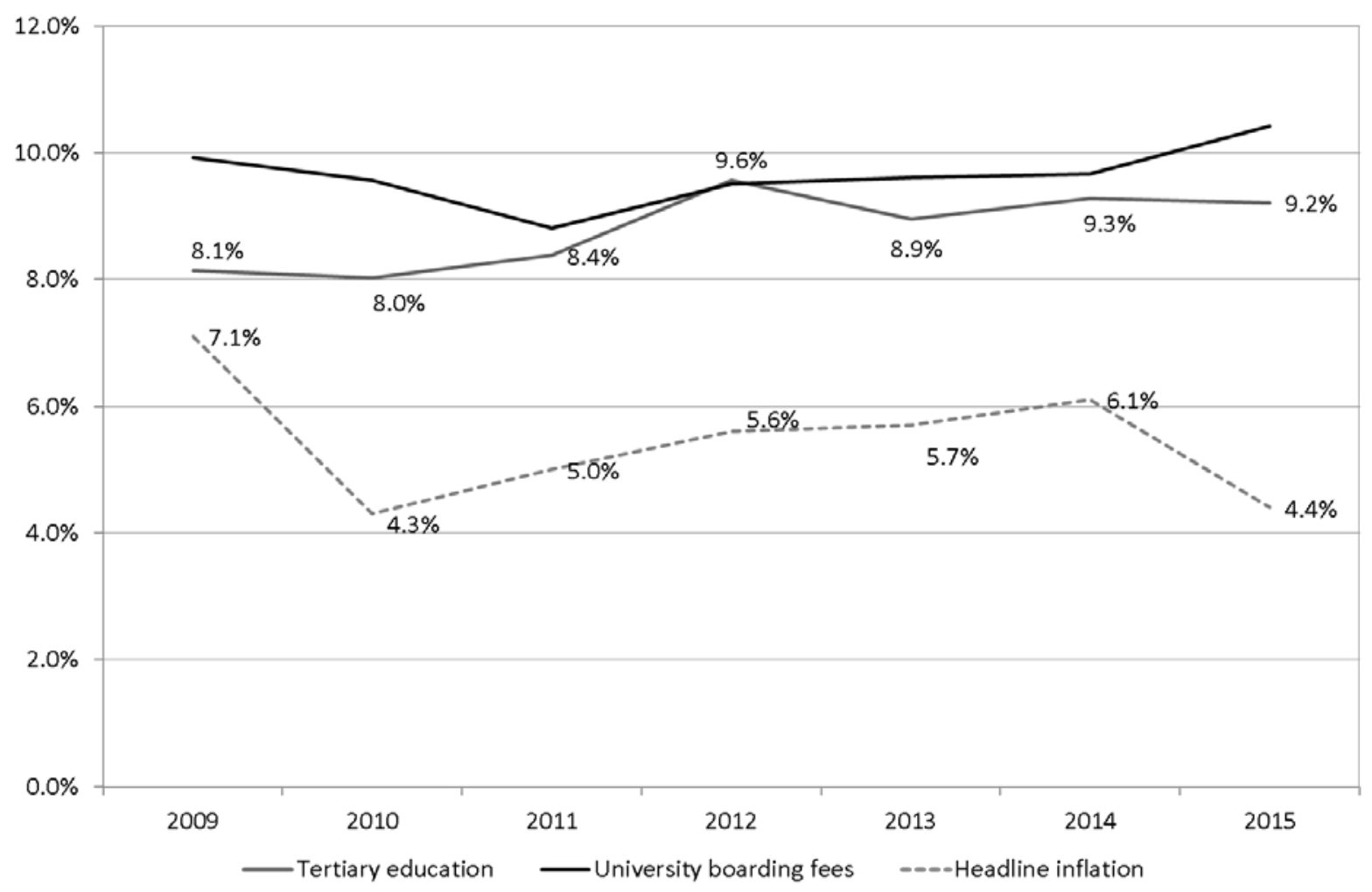

Source: StatsSA (2015)

The main reason for the hike in prices over the last two decades was the lack of government funding, the largest source of university revenue. Between 1996 and 2013, for example, higher education spending as a share of total expenditure by government declined from $4.9 \%$ to $4.7 \%$. Pressure on government to provide affordable primary and secondary education, even before the transition to democracy, is one explanation for the relative decline of tertiary education funding. ${ }^{7}$

\footnotetext{
${ }^{6}$ Wangenge-Ouma, Gerald. "Tuition fees and the challenge of making higher education a popular commodity in South Africa.” Higher Education 64.6 (2012): 831-844; Wangenge-Ouma, G., and N. Cloete. "Financing higher education in South Africa: Public funding, non-government revenue and tuition fees." South African Journal of Higher Education 22, no. 4 (2008): 906-919.

${ }^{7}$ Van der Berg, Servaas. "The transition from apartheid: Social spending shifts preceded political reform." Economic History of Developing Regions 29.2 (2014): 234-244.
} 


\section{HISTORICAL FEES: A CASE STUDY OF STELLENBOSCH UNIVERSITY}

The student protests are clearly responding to escalating fees over the last seven years. Here we want to show that this short term window is only a small part of a much larger story. For example, without considering the historical evolution of tuition fees, the rise over the last seven years may have been a short run aberration due to the global financial crisis and the limits on government spending as a result of the crisis. To test whether the student protests is a response to a short-term phenomenon or to a much longer process of fee increases, we analyse the costs of higher education in South Africa over more than a century.

We do this by focusing the analysis on one degree at the second oldest university in South Africa: a Bachelor of Arts degree at Stellenbosch University. Reconstructing long-run consumer price indices, we calculate what a BA degree in 1911, 1946, 1961, 1977, 1995, 2006 and 2015 would have cost in 2005 South African Rand. ${ }^{8}$ Table 1 provides a breakdown of the analysis.

Table 1: Analysis of Bachelor of Arts tuition fees at Stellenbosch University, 1911-20159

\begin{tabular}{|c|c|c|c|c|c|c|c|c|c|}
\hline Year & $\begin{array}{l}\text { Nominal } \\
\text { tuition } \\
\text { fees }\end{array}$ & $\begin{array}{l}\text { Real } \\
\text { tuition } \\
\text { fees (in } \\
2005 \\
\text { Rand) }\end{array}$ & CPI (in 2005) & $\begin{array}{l}\text { CPI (in } \\
2012 \text { ) }\end{array}$ & $\begin{array}{l}\text { Average } \\
\text { income per } \\
\text { adult (in } 2005 \\
\text { Rand) }\end{array}$ & $\begin{array}{l}\text { Tuition fee } \\
\text { as } \\
\text { percentage } \\
\text { of average } \\
\text { income per } \\
\text { adult }\end{array}$ & $\begin{array}{l}\text { Nominal } \\
\text { GDP per } \\
\text { capita }\end{array}$ & $\begin{array}{l}\text { Tuition fee } \\
\text { as } \\
\text { percentage } \\
\text { of GDP per } \\
\text { capita }\end{array}$ & $\begin{array}{l}\text { Factor by } \\
\text { which } \\
\text { tuition fee } \\
\text { in } 2015 \text { is } \\
\text { more } \\
\text { expensive } \\
\text { than } \\
\text { selected } \\
\text { year }\end{array}$ \\
\hline Source & $\begin{array}{l}\text { Calitz } \\
\text { (2009); SU } \\
(2015)\end{array}$ & & $\begin{array}{l}\text { Alvaredo and } \\
\text { Atikinson } \\
\text { (2010); own } \\
\text { calculations }\end{array}$ & $\begin{array}{l}\text { StatsSA } \\
(2015)\end{array}$ & $\begin{array}{l}\text { Alvaredo and } \\
\text { Atkinson } \\
(2010)\end{array}$ & & $\begin{array}{l}\text { Statistics } \\
\text { South } \\
\text { Africa } \\
(1970) \\
\text { Reserve } \\
\text { Bank } \\
(2015)\end{array}$ & & \\
\hline $1911^{\rho}$ & $17^{\lambda}$ & 7098 & 0.5 & 0.4 & 10555 & $67.2 \%$ & 52 & $65.1 \%$ & 2.5 \\
\hline 1946 & $31^{\lambda}$ & 7552 & 0.8 & 0.6 & 21059 & $35.9 \%$ & 146 & $42.5 \%$ & 2.4 \\
\hline
\end{tabular}

\footnotetext{
${ }^{8}$ We use 2005 South African rand as the base year because a more recent base year is not consistently used across all indicators.

${ }^{9}$ Statistics South Africa, 1970, Gross Domestic Product at Factor Cost, 1911-1958, Report No. 09-10-01; Estian Calitz, 2009, "How to balance your budget", in Johan Fourie \& Willem Fourie (Eds), Let's talk about Varsity (Gabbema Books: Stellenbosch), pp. 147-167; Facundo Alvaredo \& Anthony B Atkinson, 2010. "Colonial Rule, Apartheid and Natural Resources: Top Incomes in South Africa 1903-2005," OxCarre Working Papers 046, Oxford Centre for the Analysis of Resource Rich Economies, University of Oxford; Statistics South Africa, 2015, P0141 Consumer Price Index, September 2015. Available online: http://www.statssa.gov.za/publications/P0141/CPIHistory.pdf; South African Reserve Bank, 2015. Series: KBP6270J. Available online: https://www.resbank.co.za/Research/Statistics/Pages/OnlineDownloadFacility.aspx; Stellenbosch University Yearbook 2015. Student Fees. Available online: http://www.sun.ac.za/english/Documents/Yearbooks/Current/Fees.pdf
} 


\begin{tabular}{rrrrrrrrrr}
\hline \hline 1961 & 92 & 6652 & 1.4 & 1.0 & 30220 & $22.0 \%$ & 324 & $28.4 \%$ & 2.7 \\
1977 & 410 & 9823 & 4.2 & 3.1 & 37447 & $26.2 \%$ & 1333 & $30.8 \%$ & 1.8 \\
1995 & 5440 & 11261 & 48.3 & 35.9 & 31816 & $35.4 \%$ & 14320 & $38.0 \%$ & 1.6 \\
2006 & 14391 & 13753 & 104.6 & 66.4 & 37232 & $36.9 \%$ & 37899 & $38.0 \%$ & 1.3 \\
2015 & 32534 & 17915 & 181.6 & $114.6^{\alpha}$ & $40753^{\beta}$ & $44.0 \%$ & $70898^{\eta}$ & $45.9 \%$ & 1.0 \\
\hline \hline
\end{tabular}

$\rho$ Before Stellenbosch University acquired university status on 2 April 1918, it was known as Victoria College.

$\alpha$ Calculated by using monthly CPI as reported by StatsSA and assuming CPI of 116.1 for the last three months.

$\beta$ Average income per adult for 2015 is not available from the Alvaredo and Atkinson (2010) paper. We interpolate using the growth rate of GDP per capita at constant prices between 2006 and 2014.

$\eta$ GDP per capita is not yet available for 2015. We use the nominal GDP for 2014 instead. This is not an unreasonable assumption. Growth is likely to average $1 \%$ in 2015 , roughly equivalent to the increase in population size.

$\lambda$ When the South African rand replaced the British pound as currency, £1 was equal to R2. This exchange rate was used for the years before 1960.

The fee for a BA degree in 2015 at Stellenbosch University was R32 534. Rewritten in 2005 South African Rand, it amounted to R17 915. Compare that to the costs of a BA degree in earlier years: in 2006, a BA degree (all reported in 2005 Rands) cost R13 753, an increase of 30\% in only ten years. The downward trend continued, reaching a low of R6652 in 1961. In other words, as is shown in the last column, a BA degree in 2015 was 2.7 times more expensive than the same degree in 1961.10 The fee for a degree before 1961 (in our case, in 1946 and 1911) increased slightly, but it was still significantly lower than the 1977 price. In fact, there seems to have been very little change in the price of tertiary education in the first half of the twentieth century.

Of course, South Africans earn higher per capita incomes today than they did in the twentieth century and could therefore presumably afford more expensive education. Table 1 therefore also lists tuition fees as a percentage of 1) the average income per adult and 2) the GDP per capita. The percentages differ slightly between the two indicators, but the trends are similar. At the start of the twentieth century, higher education was very expensive, requiring more than $65 \%$ of average adult income. Over the next fifty years, though, because of rising incomes and steady real tuition fees, fees as a percentage of income fell dramatically to reach $22 \%$ by 1961 . Of course, higher education - notably at Stellenbosch University - was reserved for whites, which means that only a small share of the total population could benefit from these low costs of accessing higher education. In addition, much of the cost impact was alleviated by the availability of bursaries, from government, private business ${ }^{11}$ and non-profit organisations like the Helpmekaar Fund, and loans. ${ }^{12}$

\footnotetext{
${ }^{10}$ This is a lower-bound estimate. Using a different CPI deflator, we find that this factor increases to 3.2.

${ }^{11}$ Verhoef, Grietjie. "The enterprise in the society: Corporate social engagement by Sanlam, 1918-1980." Tydskrif vir Geesteswetenskappe 54.4 (2014): 731-751.

${ }^{12}$ Ehlers, Anton. "The philanthropic fruits of the 1914-15 Rebellion: the Helpmekaar - rescuing the "Volk" (people) through reading writing and arithmetic” Historia (forthcoming).
} 
By the 1970s and 1980s, real tuition fees had begun to increase. Combined with stagnating incomes and higher inflation, a larger share of adult income was necessary to attend Stellenbosch University. But even in 1995, one year after South Africa's democratic transition, tuition fees comprised a similar share of adult income as it did in 1946.

The rise in fees was thus a post-1994 phenomenon. In contrast to the rise of the two previous decades, which was largely the result of stagnating and even declining incomes, the post-1994 rise was mostly the result of rapid increases in the price of tuition. By 2006, the cost in 2005 Rands of a BA degree at Stellenbosch had risen by $22 \%$. But the negative effects of such an increase were eased by the rapidly increasing incomes of the late 1990s and early 2000s. When growth slowed, however, as had happened after the global financial crisis struck in 2007, and the increases in tuition fees did not, the consequences on students' ability to afford higher education were dire. The cost of a BA degree at Stellenbosch University had increased 30\% in the decade between 2006 and 2015, and now requires 44\% of average adult income, reminiscent of the time when higher education was a luxury good reserved for the elite.

\section{IMPLICATIONS}

The \#FeesMustFall-protests of 2015 were symptomatic of the unguided social dynamics at work when interest groups fought to escape the cost of the fiscal adjustment caused by the impact on the government budget of the financial crisis and other factors threatening fiscal sustainability. No real anticipatory leadership has been forthcoming, a manifestation of the reactionary rather than proactive nature of government priorities.

The ratio between external and internal benefits from education increases as one moves from primary to tertiary education. This is ostensibly the reason the post-1994 government prioritised primary and secondary education, even though the quality of education remained decidedly poor. ${ }^{13}$ But the low priority granted to higher education funding over the last two decades meant that universities are now caught between a rock and a hard place: the twodecade long decline in funding and the massification of tertiary education. To maintain standards, higher tuition fees were the only logical solution for university management, pushing the cost of tertiary education to historically unprecedented levels, and leading students to object.

\footnotetext{
${ }^{13}$ Spaull, Nic. "Poverty \& Privilege: Primary School Inequality in South Africa." International Journal of Educational Development 33 (2013) pp. 436-447
} 
Without substantial additional government support to reduce tuition fees as a percentage of income, as well as bursary and loan support from the private sector and not-for-profit organisations, South African universities are unlikely to return to the low tuition fee regime of the mid-twentieth century. South African campuses are thus likely to remain hotbeds of protest in the foreseeable future. 